\title{
Variasi Leksikal Di Kabupaten Kebumen (Sebuah Kajian Dialektologi)
}

\author{
Prapti Wigati Purwaningrum
}

Universitas Bina Sarana Informatika

e-mail: prapti.pwp@bsi.ac.id

\begin{tabular}{ccc}
\hline Diterima & Direvisi & Disetujui \\
$18-06-2020$ & $01-08-2020$ & $13-08-2020$ \\
\hline
\end{tabular}

\begin{abstract}
Abstrak - Penelitian ini membahas variasi leksikal di Kabupaten Kebumen pada tataran leksikon. Kabupaten Kebumen secara geografis terletak di antara Kabupaten Banyumas dengan dialek ngapak dan Kabupaten Purworejo dengan dialek bandek. Titik pengamatan dalam penelitian ini sebanyak 5 desa yang merupakan daerah-daerah yang berada dekat dengan perbatasan Kabupaten Banyumas dan Kabupaten Purworejo yaitu Desa Rowokele, Desa Bumiagung, Desa Pejagoan, Desa Kutowinangun, Desa Tunggalroso. Pengumpulan data menggunakan metode simak dan cakap. Data-data yang telah terkumpul kemudian dianalisis menggunakan metode padan dengan teknik hubung banding membedakan dan teknik hubung banding menyamakan. Hasil penelitian menunjukkan bahwa ditemukan variasi leksikon di Kabupaten Kebumen. Variasi leksikon meliputi gejala onomasiologis dan semasiologis. Variasi leksikal dipengaruhi oleh letak geografis pada titik daerah pengamatan. Selain itu ditemukan juga ternyata leksikon-leksikon tersebut dalam penggunaanya disesuaikan dengan kapan, di mana, dan kepada siapa mereka bertutur, jadi hal ini juga cukup mempengaruhi satu variasi leksikal digunakan di wilayah yang berbeda karena Kabupaten Kebumen cukup mendapat pengaruh kedua Kabupaten yaitu Banyumas dan Purworejo, jadi tuturan-tuturan yang digunakan terkadang saling bertukar dan dipahami oleh masing-masing penutur maupun mitra tuturnya. Hal ini menjadi saling melengkapi dan bervariasi pada leksikonnya.
\end{abstract}

Kata Kunci: variasi Leksikal, semasiologis, onomasiologis, Bahasa Jawa, Kabupaten Kebumen

Abstract: This study discusses the variation of Javanese language in Kebumen Regency at the level of lexicon. Observation points in this study amounted to 5 which are areas bordering Banyumas and Purworejo Regency Central Java, namely Rowokele Village, Bumiagung Village, Pejagoan Village, Kutowinangun Village, and Tunggalroso Village. Data collection uses field methods and proficient methods. The results showed that variations of the lexicon were found in Kebumen Regency. Lexicon variations include onomasiology and semasiology. The lexical variation is influenced by the geographical location at the point of observation area. In addition, it was also found that the lexicons were used according to when, where and to whom they spoke, so this also influenced one lexical variant used in different areas.

Key word: Lexical variant, semasiology, omasiology, Javanise language, Kebumen district

\section{PENDAHULUAN}

Bahasa Jawa merupakan bahasa yang memiliki jumlah pengguna paling banyak, selain itu masyarakat suku Jawa juga sudah tersebar hamper di seluruh wilayah Indonesia, maka bukan sesuatu yang mengherankan jika di mana-mana bertemu dengan orang Jawa. Mulai dari Cirebon yang merupakan perbatasan Jawa Barat dan Jawa Tengah, kadi ada sebagain pendudukan yang menggunakan bahasa Jawa, Sunda, dan campuran keduanya, serta Jawa Tengah, DI. Yogyakarta dan Jawa Timur.

Di Jawa Tengah itu sendiri terdapat dialek bahasa Jawa ngapak dan bahasa Jawa bandek. Dialek bahasa Jawa ngapak biasa digunakan di daerah Tegal, Brebes, Cilacap, Banyumas, Kebumen, sedangkan dialek bahasa Jawa bandek biasa digunakan di daerah Purworejo, Magelang, Yogyakarta, Solo, Semarang, yang cenderung tutur bahasanya halus. Namun selain daerah-daerah tersebt yang menggunakan dialek bandek dan ngapak, ada beberapa Kabupaten yang penggunaan bahasa dalam tuturannya dipengaruhi oleh dialek ngapak dan dialek bandek. Salah satu daerah tersebut adalah Kabupaten Kebumen.

Kabupaten Kebumen secara geografis termasuk wilayah Jawa Tengah letaknya tepat diapit oleh Kabupaten Banyumas dan Kabupaten Purworejo. Sehingga tidak menutup kemungkinan dialek di daerah tersebut dipengaruhi oleh dialek ngapak dari Kabupaten Banyumas dan dialek bandek dari Kabupaten Purworejo. Penelitian yang termasuk ranah kajian dialektologi di berbagai wilayah memang sudah banyak dilakukan, namun 
untuk penelitian yang khusus tentang variasi leksikal dalam satu kabupaten, seperti yang terjadi di Kabupaten Kebumen, belum pernah dilakukan. Penelitian ini fokus pada variasi leksikal yang terdapat di Kabupaten Kebumen yang secara letak geografis sangat dipengaruhi oleh dialek bahasa Jawa Ngapak dari Kabupaten Banyumas dan dialek bahasa Jawa bandek dari Kabupaten Purworejo. Selain itu perbedaan yang muncul juga dapat dipengaruhi oleh berbagai hal, terutama yang berkaitan dengan latar belakang sosial budaya masyarakat dan situasi kebahasaan di wilayah Kabupaten Kebumen. Munculnya perubahan atau variasi bahasa dalam bahasa yang dilatarbelakangi oleh perubahan budaya penuturnya (Hymes, 1983: 67).

Dalam penelitian ini, penulis mengambil satu lokasi yaitu wilayah Desa Rowokele, Kecamatan Rowokele, Kabupaten Kebumen, yang secara geografis letaknya sangat berdekatan dengan Kabupaten Banyumas, sehingga leksikon-leksikon yang digunakan oleh masyarakat tersebut dipengaruhi sangat kental oleh dialek bahasa Jawa Ngapak. Sedangkan satu kecamatan lagi yang letaknya di sebalah timur Kabupaten Kebumen yang secara geografis terletak berbatasan dengan Kabupaten Purworejo yaitu Desa Tunggalroso Kecamatan Prembun, Kabupaten Kebumen yang sebagian masyarakatnya saat bertutur terpengaruh dengan dialek bahasa Jawa bandek.

Pada penelitian kali ini penulis ingin fokus pada variasi leksikal yang terdapat di Kabupaten Kebumen, yang dipengaruhi oleh dua dialek yaitu dialek bahasa Jawa ngapak dan Dialek bahasa Jawa bandek. Perbedaan leksikal yaitu berhubungan dengan leksem-leksem yang digunakan untuk merealisasikan suatu makna yang sama tidak berasal dari satu etimon prabahasa (Mahsun, 1995). Dalam perbedaan leksikal terdapat onomasiologis yang menunjukkan nama yang berbeda berdasarkan satu konsep yang diberikan di beberapa tempat yang berbeda dan semasiologis merupakan kebalikan dari perbedaan onomasologis, yaitu pemberian nama yang sama untuk beberapa konsep yang berbeda.

Beberapa penelitian sejenis sudah pernah dilakukan khususnya dalam lingkup kajian dialektologi, beberapa penelitian tersebut membahas tentang variasi dialek di beberapa wilayah tertentu, diantaranya mencakup ranah pembeda dialek yaitu variasi fonologi, variasi leksikal seperti semasiologis dan onomasologis di pusat kota dan pinggiran di sekitar kabupaten Grobogan (Sahayu, 2003).

Penelitian sejenis juga membahas tentang variasi leksikal dan fonologis untuk menemukan bunyi klaster dan bunyi sertaan di Kabupaten Cilacap (Afidah, 2019). Selain itu terdapat juga kajian dialektologi yang mencoba masuk dalam ranah agama. Penelitan ini difokuskan pada bagaimana penggunakan dialek Bali Aga (BA) dan Bali Dataran (BD) dalam upacara adat (Mayuko, 2015).

Masih dalam lingkup yang sama, yaitu penelitian tentang dialektologi (Rahayu, 2013) mencoba mendeskripsikan bentuk variasi dialek bahasa Jawa dalam masyarakat di Kabupaten Ngawi. Selain itu dalam penelitian tersebut juga menggambarkan pola pemetaan dialek melalui variasi fonologis dan leksikal di wilayah Kabupaten Ngawi.

Penelitian berikutnya membahas bahasa gaul di Jakarta, yang ternyata ada dialek kompromi yang menjembatani 2 bahasa yaitu Betawi dan Indonesia standar, yang tekadang sulit untuk dipahami (Wouk, 1999).

Sementara dari beberapa penelitian di atas pembahasannya mencakup variasi fonologis dan variasi leksikal yang ada pada wilayah tertentu. Sementara dalam penelitian ini, penulis ingin lebih mengerucutkan lagi pada variasi leksikal dalam satu wilayah yaitu Kabupaten Kebumen yang dipengaruhi oleh dua dialek yang mengapit wlayah kabupaten tersebut. Penulis ingin mengetahui apakah ada variasi leksikal pada semasiologis dan onomasiologis di Kabupaten Kebumen yang secara geografis berada diantara dua Kabupaten yaitu Banyumas dan Purworejo.

\section{Variasi berdasarkan Penutur}

(Chaer, 2004), mengemukakan bahwa variasi menurut penutur berarti siapa yang menggunakan bahasa itu, di mana tinggalnya, bagaimana kedudukan sosialnya di dalam masyarakat, apa jenis kelaminnya dan kapan bahasa itu digunakan. berdasarkan penggunaanya, berarti bahasa itu digunakan untuk apa, dalam bidang apa, apa jalur dan alatnya, dan bagaimana situasi keformalannya. Berikut beberapa ragam dialek

1. Dialek regional merupakan varian bahasa yang dipakai di daerah tertentu. Misalnya, bahasa Indonesia dialek Jawa, Sunda, dialek Jakarta, dialek Medan.

2. Dialek sosial merupakan dialek yang dipakai oleh kelompok sosial tertentu atau yang menandai strata sosial tertentu. Misalnya, dialek remaja, dialek campuran IndonesiaInggri_(dikenal sebagai dilek jaksel).

3. Dialek temporal merupakan yaitu dialek yang dipakai pada kurun waktu tertentu. Misalnya, dialek Melayu zaman Sriwijaya dan dialek Melayu zaman Abdullah. 
(Ayatrohaedi, 2002a) mengemukakan bahwa dialek memiliki dua ciri, yaitu: (1) seperangkat bentuk ujaran setempat yang berbeda-beda yang memiliki ciri-ciri umum dan masing-masing memiliki lebih mirip sesamanya dibandingkan dengan bentuk ujaran lain dari bahasa yang sama dan (2) dialek tidak harus mengambil semua bentuk ujaran dari sebuah bahasa.

Menurut (Ayatrohaedi, 2002b) "Dialek mengacu ke sumua perbedaan antar variasi bahasa yang satu dan yang lain mencakup penggunaan tata bahasa, kosakata maupun aspek ucapannya". Berdasarkan uraian di atas dapat disimpulkan bahwa dialek adalah variasi bahasa dari sekelompok penutur dalam bentuk tuturan setempat yang merupakan hasil perbandingan dengan salah satu isolek lainnya.

Pembeda Dialek terdiri dari lima macam perbedaan, yaitu :

1. Perbedaan fonetik : perbedaan ini berada dibidang fonologi dan biasanya pemakai dialek/ bahasa yang bersangkutan tidak menyadari adanya perbedaan tersebut.

2. Perbedaan semantik: dengan terciptanya katakata baru berdasarkan perubahan fonologi dan geseran bentuk.

3. Perbedaan onomasiologis : menunjukkan nama yang berbeda berdasarkan satu konsep yang diberikan dibeberapa tempat yang berbeda.

4. Perbedaan semasiologis : pemberian nama yang sama untuk beberapa konsep yang berbeda

5. Perbedaan morfologis : terciptanya inovasi bahasa.

\section{METODE PENELITIAN}

Metode yang digunakan dalam penelitian ini adalah metode simak dan cakap. Metode simak disejajarkan dengan metode observasi dalam penelitian sosial (Sudaryanto, 2015). Sedangkan Metode cakap disejajarkan dengan metode wawancara dalam penelitian sosial (Sudaryanto, 2015) Dalam penelitian ini, peneliti melakukan wawancara kepada responden dan dilakukan dengan merekam dan mencatat setiap berian yang diberikan oleh responden berkenaan dengan daftar tanya atau percakapan spontan yang keluar dari mereka dengan menggunakan teknik pancing dengan tujuan terarah, mengulang pertanyaan.

\section{Objek Penelitian}

Objek dalam penelitian ini adalah berian kata-kata bahasa Jawa baik dialek ngapak atau dialek bandek yang sesuai dengan berian daftar tanya atau kata-kata yang secara spontanitas keluar dari responden melalui teknik pemancingan.

\section{Sumber data}

Berupa dafatar pertanyaan yang telah diisi oleh para informan, dan jika ada yang sulit atau informan kurang memahami pertanyaan, dipersilahkan bertanya pada peneliti, begitupun sebaliknya.

\section{Informan}

Dalam sebuah penelitian diperlukan informan. Adapun kriteria Informan sebagai berikut:

1. berjenis kelamin pria atau wanita

2. berusia antara $25-65$ tahun;

3. berstatus sosial menengah; memiliki kebanggaan terhadap bahasanya; sehat jasmani dan rohani.

Penelitian dialektologi memerlukan banyak informan sehingga dapat diperoleh gambaran yang lebih objektif mengenai situasi kebahasaan setempat. (Samarin, 1988)(Samarin, 1988: 28). Dalam penelitian ini akan menggunakan 2-3 orang responden yang menggunakan dialek ngapak dan bandek, satu sebagai responden utama, sedangkan yang lain hanya sebagai pembanding.

\section{HASIL DAN PEMBAHASAN}

Variasi leksikal di wilayah Kabupaten Kebumen yang dipengaruhi oleh dialek bahasa Jawa ngapak dan dialek bahasa Jawa bandek. Pada wilayah Kabupaten Kebumen tuturan dipengaruhi keduanya karena letak wilayah secara geografis.

Gambar 1. Peta Kabupaten Kebumen

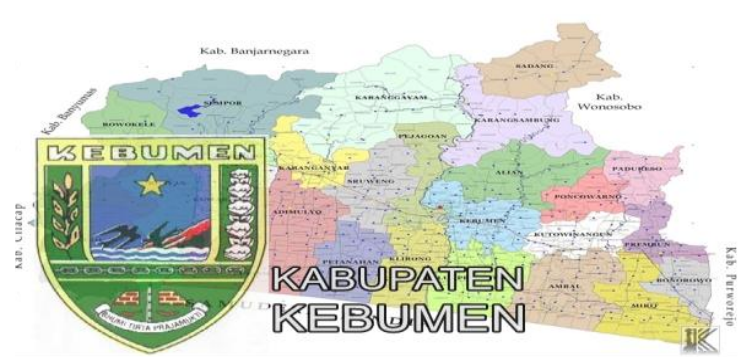


Tabel 1. Tempat Penelitian

\begin{tabular}{|c|c|}
\hline NOMOR & DAERAH \\
\hline TP I & Desa Rowokele \\
\hline TP II & Desa Bumiagung \\
\hline TP III & Desa Pejagoan \\
\hline TP IV & Desa Kutowinangun \\
\hline TP V & Desa Tunggalroso \\
\hline
\end{tabular}

Pada masing-masing daerah di atas diambil beberapa informan untuk dilakukan penelitian bahasanya. Pengambilan informan ini secara acak, namun informan yang dipilih tetap sesuai dengan kriteria dalam penelitian dialek. Dari penelitian yang dilakukan pada semua daerah pengamatan diperoleh data sebagai berikut:
Di Kabupaten Kebumen ternyata tidak semua mayarakatnya bertutur menggunakan dialek ngapak, namun bagi wilayah timur yang semakin mendekat perbatasan dengan Kabupaten Purworejo, maka dialek yang digunakan adalah bandek. Dari pengamatan penulis memperoleh 21 variasi leksikal, Variasi leksikal yang ditemukan ini setidaknya minimal memiliki dua buah berian pada setiap gloss. Adanya variasi pada setiap daerah pengamatan dapat dipengaruhi oleh berbagai faktor, salah satunya adalah letak geografis daerah pengamatan. Semua variasi leksikal yang ada ini diasumsikan dapat mewakili situasi kebahasaan di wilayah Kabupaten Kebupaten yang dipengaruhi oleh dua dialek ngapak dan bandek, dan variasi dialek yang ada ini mengacu pada dialek di Jawa Tengah.

Tabel 2. Perbandingan Glos Pada Gejala Onomasiologis dan Semasiologis Di 5 (lima) Wilayah

\begin{tabular}{|c|c|c|c|c|c|c|c|c|c|c|c|c|c|}
\hline \multirow[b]{2}{*}{ Daerah } & \multicolumn{8}{|c|}{ Gejala Onomasiologis } & \multicolumn{5}{|c|}{ Gejala Semasiologis } \\
\hline & $\begin{array}{c}\text { Bagian } \\
\text { tubuh }\end{array}$ & Sapaan & Peralatan & Benda & Tanaman & Hewan & $\begin{array}{l}\text { Gerak } \\
\text { Tubuh }\end{array}$ & $\begin{array}{l}\text { Bagian } \\
\text { Rumah }\end{array}$ & $\begin{array}{c}\text { Keadaan } \\
\text { Alam }\end{array}$ & Tanaman & $\begin{array}{l}\text { Bagian } \\
\text { Rumah }\end{array}$ & Benda & $\begin{array}{l}\text { Kata } \\
\text { Sifat }\end{array}$ \\
\hline TP I & $\begin{array}{l}\text { [caykəm] } \\
\text { [tutu?] }\end{array}$ & [ḍew\&k] & $\begin{array}{l}\text { [tfantuk] } \\
\text { dan } \\
\text { [tidok] }\end{array}$ & [kukus] & [bodhin] & [kampræt] & [mənyat] & $\begin{array}{l}\text { [pedhayan] } \\
\text { dan } \\
\text { [pawon] }\end{array}$ & $\begin{array}{l}\text { [awv] } \\
\text { /sisa } \\
\text { pembakaran/ }\end{array}$ & $\begin{array}{l}\text { [lombok] } \\
\text { /cabe } \\
\text { rawit/ \& } \\
\text { /cabe } \\
\text { merah/ }\end{array}$ & $\begin{array}{l}\text { [pawon] } \\
\text { /seperti } \\
\text { kompor } \\
\text { tp terbuat } \\
\text { dr tanah } \\
\text { liat }\end{array}$ & $\begin{array}{l}\text { [wedhay] } \\
\text { /Air yg } \\
\text { sedang } \\
\text { direbus/ }\end{array}$ & $\begin{array}{l}\text { [langka] } \\
\text { /tidak } \\
\text { ada sama } \\
\text { sekali/ }\end{array}$ \\
\hline TP II & $\begin{array}{l}\text { [caykəm] } \\
\text { [tutu?] }\end{array}$ & [ḍewek] & $\begin{array}{l}\text { [fantuk] } \\
\text { dan } \\
\text { [tidok] }\end{array}$ & [kukus] & [bodhin] & [kampræt] & [mənyat] & $\begin{array}{l}\text { [pedhayan] } \\
\text { dan } \\
\text { [pawon] }\end{array}$ & $\begin{array}{l}{[\text { awv }]} \\
\text { /sisa } \\
\text { pembakaran/ }\end{array}$ & $\begin{array}{l}\text { [lombok] } \\
\text { /cabe } \\
\text { rawit/ \& } \\
\text { /cabe } \\
\text { merah/ }\end{array}$ & $\begin{array}{l}\text { [pawon] } \\
\text { /seperti } \\
\text { kompor } \\
\text { tp terbuat } \\
\text { dr tanah } \\
\text { liat }\end{array}$ & $\begin{array}{l}\text { [wedhay] } \\
\text { /Air yg } \\
\text { sedang } \\
\text { direbus/ }\end{array}$ & $\begin{array}{l}\text { [langka] } \\
\text { /ada, tapi } \\
\text { hanya } \\
\text { beberapa/ }\end{array}$ \\
\hline TP III & $\begin{array}{l}\text { [caykəm] } \\
\text { [tutu?] }\end{array}$ & [ḍewek] & $\begin{array}{l}\text { [tantuk] } \\
\text { dan } \\
\text { [tid } v k]\end{array}$ & [kukus] & [bodhin] & [kampræt] & [mənyat] & [pawon] & $\begin{array}{l}\text { [awv] } \\
\text { /sisa } \\
\text { pembakaran/ }\end{array}$ & $\begin{array}{l}\text { [lombok] } \\
\text { /cabe } \\
\text { rawit/ \& } \\
\text { /cabe } \\
\text { merah/ }\end{array}$ & $\begin{array}{l}\text { [pawon] } \\
\text { /dapur/ }\end{array}$ & $\begin{array}{l}\text { [wedhay] } \\
\text { /Jenis } \\
\text { minuman: } \\
\text { kopi, teh, } \\
\text { susu/ }\end{array}$ & $\begin{array}{l}\text { [langka] } \\
\text { /ada, tapi } \\
\text { hanya } \\
\text { beberapa/ }\end{array}$ \\
\hline TP IV & $\begin{array}{l}\text { [caykəm] } \\
\text { [tutu?] }\end{array}$ & $\begin{array}{l}\text { [kito] } \\
\text { dan } \\
\text { [kawulo] }\end{array}$ & [siwur] & [kəbul] & [telo] & [ţodhot] & [yadhəg] & [pawon] & $\begin{array}{l}\text { [awv] } \\
/ \text { debu/ }\end{array}$ & $\begin{array}{l}\text { [lombok] } \\
\text { /cabe } \\
\text { rawit/ \& } \\
\text { /cabe } \\
\text { merah/ }\end{array}$ & $\begin{array}{l}\text { [pawon] } \\
\text { /dapur/ }\end{array}$ & $\begin{array}{l}\text { [wedhay] } \\
\text { /Jenis } \\
\text { minuman: } \\
\text { kopi, teh, } \\
\text { susu/ }\end{array}$ & $\begin{array}{l}\text { [langka] } \\
\text { /ada, tapi } \\
\text { hanya } \\
\text { beberapa/ }\end{array}$ \\
\hline TP V & $\begin{array}{l}\text { [caykəm] } \\
\text { [tutu?] }\end{array}$ & $\begin{array}{l}\text { [kito] } \\
\text { dan } \\
\text { [kawulo] }\end{array}$ & [siwur] & [kəbul] & [telo] & [ţodhot] & [yadhəg] & [pawon] & $\begin{array}{l}\text { [awv] } \\
/ \text { debu/ }\end{array}$ & $\begin{array}{l}\text { [lombok] } \\
\text { /cabe } \\
\text { rawit/ \& } \\
\text { /cabe } \\
\text { merah/ }\end{array}$ & $\begin{array}{l}\text { [pawon] } \\
\text { /dapur/ }\end{array}$ & $\begin{array}{l}\text { [wedhay] } \\
\text { /Jenis } \\
\text { minuman: } \\
\text { kopi, teh, } \\
\text { susu/ }\end{array}$ & $\begin{array}{l}\text { [langka] } \\
\text { /ada, tapi } \\
\text { hanya } \\
\text { beberapa/ }\end{array}$ \\
\hline
\end{tabular}

\section{Gejala Onomasiologis}

Gejala onomasiologis yang ditemukan dalam bahasa Jawa dialek ngapak dan dialek bandek di Kabupaten Kebumen yang diapit oleh Kabupaten Banyumas dan Kabupaten Purworejo, hal ini mengakibatkan ada beberapa tuturan masyarakat dipengaruhi oleh kedua dialek tersebut. Malalui pengamata, terdapat pada medan makna (1) bagian tubuh, (2) kata ganti atau sapaan (3) peralatan, (4) benda (5) tanaman (6) hewan (7) gerak tubuh (8) bagian rumah.

Pada medan makna bagian tubuh, gejala onomasiologis ditemukan pada gloss /mulut/ yang ditandai dengan leksikon [cankəm] untuk TP-1 dan TP-2 namun sebagian, [tutu?] untuk TP-2 sebagaian dan TP-3. Ternyata di TP IV dan TP V juga ada yang menggunakan [cangkəm] dan [tutu?]. Pada saat dikonfirmasi, keduanya digunakan dalam situasi tertentu, kapan dan dengan siapa mereka bertutur. Misalnya, saat anak berbicara kepada orang tua atau orang yang dituakan, maka akan memilih leksikon [tutu?]. Sedangkan leksikon [cangkem] digunakan saat seseorang bertutur dengan teman sebaya. Pada medan makna bagian tubuh, terdapat gejalan onomasiologis, terdapat /mata kaki/ ada laksikon [əntho]-[əntho] yang dituturkan oleh masyarakat di TP I, TP II, dan TP III, sedangkan untuk leksikon [pəl॰k] atau [pəlっ?], munculnya bunyi glottal ini 
biasanya untuk menggantikan bunyi [k] karena biasanya dialek bandek tidak menuturkan bunyi [k].

Pada medan makna kata ganti, sapaan, dan acuan, gejala onomasiologis ditemukan pada gloss 'kita' yang ditandai dengan leksikon [dewek] di TPI, TP-II, TP III sedangkan [kito] dan [kawulo] di TPIV dan TP V. namun saat dikonfirmasi kembali, responden menjelaskan bahwa penggunaanya kembali disesuaikan dengan siapa dan kapan tuturan tersebut terjadi.

Pada medan makna peralatan, gejala onomsiologis terdapat pada gloss /gayung/ ada leksikon [tantuk] dan [tfidok] dituturkan oleh masyarakat TP I, TP II dan TP III. Namun biasanya mereka akan membedakan berdasarkan bahan dasarnya, biasanya yang terbuat dari bahan dasar bamboo dan batok kelapa, sedangkan [tidok] bahan dasarnya terbuat dari bahan plastik yang sudah umum digunakan oleh masyarakat saat ini. Sementara leksikon [siwur] dituturkan di daerah TP IV dan TP V.

Untuk medan makna benda, terdapat gejala onomasiologis terdapat pada gloss /asap/ pada leksikon [kokus] dituturkan oleh sebagaian masyarakat di wilayah TP I, TP II, dan TP III. Leksikon [kokus] ini ditujukan untuk segala bentuk asap yang keluar dari pembakaran sampah dan saat memasak. Sedangkan leksikon lainnya [kəbol] biasa dituturkan oleh masyarakat di TP IV dan TP V. Gloss berikutnya /debu/ ada leksikon [blədhog] biasa dituturkan di TP I, TP II, TP III, dan untuk [awo] terdapat di TP IV dan TP V.

Untuk medan makna tanaman, terdapat gejalan onomasiologis, terdapat pada gloss /ubi kayu/ ada leksikon [bodhin] dituturkan di sebagian masyarakat TP I, TP II, dan TP III. Sedangkan pada leksikon [telo] sering dituturkan oleh masyarakat di TP IV dan TP V.

Untuk medan makna binatang, tedapat gejala onomasiologis pada gloss /kelelawar/ ada leksikon [kampræt] biasa dituturkan di TP I, II, III dan leksikon [tfodhot] dituturkan di TP IV dan V. Namun setelah dikonfirmasi kembali, di TP I, TP II, TP III, TP IV, dan TP V ada beberapa juga yg menuturkan [kampræt] dan [tfodhot]. Hal ini di dasarkan pada jenis benda yang dimakan, masyarakat akan

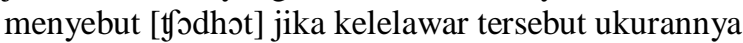
besar dan memakan biji-bijian dan pada umumnya pisang dan beberapa buah-bahan. Sedangkan untuk [kampræt] memiliki ukuran yang lebih kecil dari [ţodhot] dan memakan serangga.

Pada medan makna aktifitas atau gerak tubuh juga terdapat gejala onomasiologis pada gloss /bangun dari duduk/ ada leksikon [mənyat] dituturkan oleh maysarakat di TP I, TP II, dan TP
III, sedangkan untuk leksikon [yadhəg] banyak dituturkan di TP IV dan TP V. namun menurut keterangan informan dari masing-titk penelitian terkadang menuturkan keduanya.

Pada medan makna bagian rumah terjadi gejala onomasiologis seperti pada gloss /dapur/ memiliki leksikon [pedhayan] dan [pawon] sering dituturkan oleh masyarakat TP I dan TP II, sedangkan pada TP IV dan V sering menuturkan leksikon [pawon]. Namun di TP I dan TP II juga ada beberapa yang menuturkan [pawon].

\section{Gejala Semasiologis}

Pada medan makna tanaman gejala semasiologis ditemukan pada leksikon [lombok], yang digunakan untuk menandai dua gloss yang berbeda yaitu /cabai rawit/ dan /cabai merah/ di TP I, TP II, TP III, TP IV, dan TP V.

Untuk medan makna keadaan alam terjadi gejalan semasiologis ditemukan pada leksikon [awo], yang digunakan untuk menandai dua gloss yang berbeda yaitu /debu/ di TP IV dan TP V, sedangkan untuk/sisa pembakaran/ digunakan di TP I, TP II, dan TP III.

Gajala semasiologis berikutnya ditemukan bagian rumah pada leksikon [pawon], yang digunakan untuk menandai dua gloss yang berbeda yaitu /dapur/ di TP III, IV, V sedangkan laksikon /alat masak yang terbuat dari batu atau tanah, gloss ini masih sering digunakan di TP I dan TP II, namun sebagaian masyarakat di daerah tersebut juga ada yang menggunakan leksikon [pawon] yang mengacu pada gloss /dapur/.

Pada medan makna benda leksikon [wedhan] digunakan untuk menandai dua gloss yang berbeda yaitu /air yang sedang atau sudah direbus/ digunakan di TP I, TP II, dan TP III, sedangkan gloss berikutnya /segala bentuk minuman teh, kopi, susu, air tawar/ umumnya digunakan di TP IV dan TP V. peneliti pernah mengkonfirmasi di TP II, ternyata leksikon [wedhan] juga sering merujuk pada benda seperti yang ada pada TP IV dan TP V yaitu wedhang kopi, teh, atau susu.

Pada medan makna untuk kata sifat leksikon [langka] digunakan untuk menandai dua gloss yang berbeda yaitu /sesuatu yang tidak ada/ digunakan di TP I, sedangkan untuk /sesuatu yang masih ada tapi sedikit/ yang dituturkan di TP II, TP III, TP IV, TP V. Saat dikonfirmasi kembali ternyata leksikon langka yag merujuk pada sesuatu yang tidak ada juga sering dituturka juga di wilayah II. 


\section{KESIMPULAN}

Bahasa Jawa khususnya di Kabupaten Kebumen juga memiliki variasi leksikon, yaitu gejala onomasiologis dan semasiologis pada medan makna tertentu. Variasi-variasi tersebut sudah dijabarkan dalam pembahasan termasuk cakupan tempat pengamatan sebagai pengguna variasi bahasa tersebut. Munculnya variasi leksikon khususnya bahasa Jawa bandek dan bahasa Jawa ngapak di Kabupaten Kebumen disebabkan oleh letak geografis daerah pengamatan yang diapit oleh kabupaten Bnayumas dan Kabupaten Purworejo. Selain letak geografis, ternyata kontak bahasa antarpenutur di masing-masing daerah pengamatan serta tingkat pengetahuan dan pendidikan penutur menjadi penyebab terjadinya variasi bahasa Jawa di Kabupaten Kebumen, khususnya di Kecamatan Rowokele yang berbatasan langsung dengan Kabupaten Banyumas dan Kecamatan Kutowinangun yang letaknya semakin mendekat dengan Kabupaten Purworejo.

Selama pengamatan di titik-titik daerah pengamatan tentang variasi Leksikon, penulis beberapa mengkonfirmasi tentang beberapa penggunaan leksikon seperti pada gloss /mulut/ dengan leksikon [cangkəm] dan [tutu?], ternyata kadang digunakan di semua tempat pengamatan, tapi penggunaanya disesuaikan dengan kapan dan kepada siapa mereka bertutur.

Selain itu ternyata masing-masing gejala seperti onomasiologis dan semasiologis tidak terlalu memiliki perbedaan yang jauh, karena Kabupaten Kebumen cukup mendapat pengaruh kedua Kabupaten yaitu Banyumas dan Purworejo, jadi tuturan-tuturan yang digunakan terkadang saling bertukar dan dipahami oleh masing-masing penutur maupun mitra tuturnya. Hal ini menjadi saling melengkapi dan bervariasi pada leksikonnya.

Penelitian ini masih sangat sederhana karena cakupannya masih lingkup kajian geografi dialek, dan masih sangat memungkinkan untuk diakukan penelitian lebih lanjut di Kabupaten Kebumen ini dengan menggunakan penghitungan dialektometri dengan cakupan lebih luas lagi pada tataran variasi fonologis dan morfologis.

Tabel 3. Daftar Pertanyaan (Dalam Kajian Dialektologi Di Kabupaten Kebumen)

\begin{tabular}{|l|l|l|l|}
\hline $\begin{array}{c}\text { Medan } \\
\text { Makna } \\
\text { Bagian } \\
\text { Tubuh }\end{array}$ & $\begin{array}{l}\text { Medan Makna } \\
\text { Bagian Rumah }\end{array}$ & $\begin{array}{c}\text { Medan } \\
\text { Makna } \\
\text { Peralatan }\end{array}$ & $\begin{array}{l}\text { Medan } \\
\text { Makna } \\
\text { Binatan } \\
\text { gan }\end{array}$ \\
\hline $\begin{array}{l}\text { alis, bahu, } \\
\text { betis, } \\
\text { bibir, } \\
\text { dada, gigi, }\end{array}$ & $\begin{array}{l}\text { atap, dapur, } \\
\text { tembok, } \\
\text { genteng, } \\
\text { jendela, kamar }\end{array}$ & $\begin{array}{l}\text { alu, bakul, } \\
\text { bantal, } \\
\text { cobek, } \\
\text { dingkilk, }\end{array}$ & $\begin{array}{l}\text { Kelelaw } \\
\text { ar }\end{array}$ \\
\hline
\end{tabular}

\begin{tabular}{|l|l|l|l|}
\hline gusi, hati, & tidur, kamar & gelas,cawan & \\
hidung, & mandi, kandang & /tatakan, & \\
ibu jari, & ayam, kandang & jarum, & \\
janggut, & kambing, & lesung, & \\
jari, & kandang kerbau, & pancing, & \\
kelingking & kandang kuda, & piring, \\
kai, & kandang & pisau, & \\
kepala, & burung, langit- & selimut, & \\
ketiak, & langit rumah, & sendok, & \\
kuku, & pagar, pintu, & tempat & \\
kulit, & rumah kecil & beras, & \\
kumis, & tengah sawah, & tempat nasi, \\
leher, & tangga, tiang, & tempayan, & \\
lengan, & tungku, ruang & tikar, & \\
lidah, & depan yang & ulekan, & \\
mata, mata & terbuka, ruang & wajan & \\
kaki. & rumah paling & \\
& belakang, & \\
\hline
\end{tabular}

\section{REFERENSI}

Afidah, A. U. dan H. B. M. (2019). Variasi Fonologi dan Leksikon Bahasa Jawa di Kabupaten Cilacap (Kajian) Geografi Dialek di Perbatasan Jawa-Sunda. Jurnal Sastra Indonesia, 8(2), 103-110.

Ayatrohaedi. (2002a). Pedoman Praktis: Penelitian Dialektologi. Jakarta: Pusat Pembinaan dan Pengembangan Bahasa Depdikbud.

Ayatrohaedi. (2002b). Pedoman Praktis: Penelitian Dialektologi. Jakarta: Pusat Pembinaan dan Pengembangan Bahasa Depdikbud.

Chaer, A. (2004). Sosiolinguistik Perkenalan Awal. Jakarta: Renika Cipta.

Mahsun. (1995). Dialektologi Diakronis: Sebuah Pengantar (Gajah Mada University Press, ed.). Yogyakarta.

Mayuko, H. (2015). “ Bentuk Hormat " Dialek Bahasa Bali Aga Dalam. Jurnal Ilmiah Masyarakat Linguistik Indonesia, 33(2), 121133.

Rahayu, I. M. (2013). Variasi Dialek Bahasa Jawa Di Wilayah Kabupaten Ngawi: Kajian Dialektologi. Skriptorium, 1(2), 27-34.

Sahayu, W. (2003). Variasi Fonologis Pemakaian Bahasa Jawa di Pusat Kota dan Daerah Pinggiran Bagian Utara Kabupaten Grobogan. HUMANIORA, 15(3), 336-344.

Samarin, W. J. (1988). Ilmu Bahasa Lapangan. Yogyakarta: Kanisius.

Sudaryanto. (2015). Metode dan Teknis Analisis Bahasa: Pengantar Penelitian Wahana Budaya Secara Linguistik. Yogyakarta: Sanata 
Darma University Press.

Wouk, F. (1999). Dialect contact and koineization in Jakarta, Indonesia. Language Sciences, 21(1), 61-86. https://doi.org/10.1016/S03880001(98)00013-8 